\title{
$\square$

\section{SISTEM INFORMASI DONOR DARAH BERBASIS ANDROID PADA UNIT TRANSFUSI DARAH PALANG MERAH INDONESIA (UTD PMI) KOTA PEKANBARU}

\author{
Rizky Wahyu Syahputra ${ }^{1}$, Anita Febriani ${ }^{2}$, Rika Melyanti ${ }^{3}$ \\ Teknik Informatika, STMIK Hang Tuah Pekanbaru
}

Email :

rizkywahyus09@gmail.com ${ }^{1}$, nitasuheri@gmail.com ${ }^{2}$, camelya2105@gmail.com $^{3}$

\begin{abstract}
Darah merupakan salah satu bagian terpenting dalam tubuh manusia dikarenakan darah memiliki fungsi untuk mengedarkan sari makanan, mengangkut oksigen, mengedarkan hormon, dan lain-lain. Jika manusia mengalami kekurangan darah yang diakibatkan oleh kecelakaan atau terserang penyakit anemia sehingga manusia tersebut kekurangan darah atau bahkan menyimpan darah kotor dalam tubuh, maka hal tersebut dapat menyebabkan penyakit yang membahayakan kesehatan bahkan nyawa seseorang. Kegiatan donor darah merupakan suatu kegiatan proses pemindahan darah dari seorang pendonor kepada orang yang kekurangan darah yang prosesnya dilakukan oleh pihak yang berwenang melakukan proses pengolahan darah seperti Unit Transfusi Darah (UTD) dibawah naungan Palang Merah Indonesia (PMI). UTD PMI Kota Pekanbaru hanya memiliki sistem informasi donor darah berbasis web sehingga UTD PMI Kota pekanbaru ingin mengikuti zaman dimana banyak pengguna menggunakan smartphone maka dari itu mereka ingin meningkat dari versi web ke versi android. Alasan peningkatan sistem ini bertujuan untuk pengurangan biaya hosting yang harus dibayar pada saat penggunaan sistem web dan sistem informasi berbasis Android tidak terlalu banyak membutuhkan pengetikan ketika pengguna akan melakukan suatu perintah terhadap sistem, penggunaannya tidak terbatas oleh ruang dan tempat, serta tidak terlalu membutuhkan koneksi yang prima untuk menjalankan sistem. Sistem Informasi Donor Berbasis Android Pada Unit Transfusi Darah Palang Merah Indonesia (UTD PMI) Kota Pekanbaru diharapkan dapat membantu semua kalangan masyarakat untuk mengetahui tentang informasi tentang donor darah dengan baik dengan menggunakan Smartphone yang berbasis android sebagai media yang menarik.
\end{abstract}

Keywords: Donor Darah, Android, UTD PMI

\section{Abstrak}

Blood is one of the most important parts in the human body because blood has a function to circulate the juice, carry oxygen, circulate hormones, and others. If humans reduce blood caused by accidents or anemia, so that humans lack blood or store dirty blood in the body, then it can cause diseases that endanger the health of even someone. Blood donor activity is an activity of the process of blood transfer from donors to people who lack blood. The process is carried out by those who carry out blood processing processes such as the Blood Transfusion Unit (UTD) under the auspices of the Indonesian Red Cross (PMI). UTD PMI Pekanbaru City only has a web-based blood donor information system, so UTD PMI Pekanbaru City wants to keep up with the times where many users use smartphones so they want to upgrade from the web version to the Android version. The reason for the improvement of this system aims to reduce hosting costs to be paid when using a web system and Android-based information system does not require typing too much when the user will carry out an order to the system, its use is not limited by space and place, and does not really need a connection that is prime to run the system. Android-Based Donor Information System in the Indonesian Red Cross Blood Transfusion Unit (UTD PMI) Pekanbaru City can help all people to find out about information about blood donations well by using Android-based smartphones as interesting media.

Keywords: Blood Donor, Android, UTD PMI 


\section{PENDAHULUAN}

Darah merupakan salah satu bagian terpenting dalam tubuh manusia dikarenakan darah memiliki fungsi untuk mengedarkan sari makanan, mengangkut oksigen, mengedarkan hormon, dan lain-lain. Jika manusia mengalami kekurangan darah yang diakibatkan oleh kecelakaan atau terserang penyakit anemia sehingga manusia tersebut kekurangan darah atau bahkan menyimpan darah kotor dalam tubuh, maka hal tersebut dapat menyebabkan penyakit yang membahayakan kesehatan bahkan nyawa seseorang. Oleh sebab itu, maka kegiatan donor darah sangat diperlukan untuk menghindari terjadinya kekurangan darah tersebut.

Kegiatan donor darah merupakan suatu kegiatan proses pemindahan darah dari seorang pendonor kepada orang yang kekurangan darah yang prosesnya dilakukan oleh pihak yang berwenang melakukan proses pengolahan darah seperti Unit Transfusi Darah (UTD) dibawah naungan Palang Merah Indonesia (PMI).

Unit Transfusi Darah Palang Merah Indonesia (UTD PMI) Kota Pekanbaru merupakan organisasi yang bergerak dalam bidang pelayanan kesehatan atau kegiatan sosial, khususnya kegiatan donor darah dan pelayanan permintaan darah bagi masyarakat yang membutuhkan darah diwilayah Kota Pekanbaru.

Maka pada penelitian ini dibuat sistem informasi donor darah berbasis android yang bertujuan untuk memberikan informasi kepada masyarakat khususnya masyarakat yang berada di wilayah Kota Pekanbaru tentang informasi donor darah. Pemilihan android sebagai metode pengolahan sistem donor darah ini dikarenakan android merupakan salah satu sistem yang sudah familiar dibeberapa kalangan masyarakat, baik dari anakanak hingga orang dewasa sehingg diharapkan sistem informasi donor darah ini lebih bersifat user friendly.

\section{METODE PENELITIAN}

Metode rekayasa perangkat lunak yang digunakan adalah metode waterfall. Secara garis besar metode waterfall mempunyai langkah-langkah, diantaranya :

\section{Analisa Kebutuhan}

Langkah ini merupakan analisa terhadap kebutuhan sistem. Pengumpulan data dalam tahap ini bisa melakukan sebuah penelitian, wawancara, atau studi literatur. Sistem analis akan menggali informasi sebanyak-banyaknya dari user sehingga akan tercipta sebuah sistem komputer yang bisa melakukan tugastugas yang diinginkan oleh user tersebut. Tahapan ini akan menghasilkan dokumen user requirment atau bisa dikatakan sebagai data yang berhubungan dengan keinginan user dalam pembuatan sistem. Dokumen ini lah yang akan menjadi acuan sistem analis untuk menerjemahkan ke dalam bahasa pemrogram.

\section{Desain Sistem}

Tahapan dimana pengembang dapat membuat perancangan sistem sesuai dengan analisa yang telah dilakukan pada tahap sebelumnya, sehingga sistem yang dibuat dapat menjadi solusi dari permasalahan yang ada. Desain sistem yang digunakan pada sistem informasi berbasis android ini adalah perancangan sistem menggunakan UML (Unified Modeling Language).

3. Penulisan Kode Program

Penulisan kode program atau coding merupakan penerjemahan design dalam bahasa yang bisa dikenali oleh komputer. Penulisan kode program ini dilakukan oleh seorang yang disebut programmer yang akan menterjemahkan transaksi atau keinginan user. Tahapan ini lah yang merupakan tahapan secara nyata dalam mengerjakan suatu sistem. Dengan kata lain, pada tahap ini penggunaan komputer akan dimaksimalkan. Setelah pengkodean selesai maka akan dilakukan pengujian terhadap program atau sistem yang telah dibuat. Tujuan dilakukannya pengujian adalah untuk menemukan kesalahan-kesalahan atau error pada sistem, memastikan sistem dapat berjalan dengan lancar, dan memastikan bahwa sistem yang dibuat sudah sesuai dengan keinginan user. Penulisan kode program dalam pembuatan sistem informasi donor darah ini menggunakan bahasa Java dan dikembangkan menggunakan aplikasi Android Studio.

\section{Pengujian Program}

Tahapan akhir dimana sistem yang baru diuji kemampuan dan keefektifannya sehingga didapatkan kekurangan dan kelemahan sistem yang kemudian dilakukan pengkajian ulang dan perbaikan terhadap aplikasi menjadi lebih baik dan sempurna.

\section{Penerapan dan Pemeliharaan Program}

Pada tahapan ini merupakan tahapan dimana perangkat lunak sudah siap pakai dan sudah sesuai dengan keinginan pengguna atau user. Namun, tahap penerapan ini harus dibarengi dengan tahapan pemeliharaan yang berguna untuk menjaga agar sistem atau perangkat lunak tetap bekerja sesuai dengan fungsinya. Pada tahapan ini juga akan dilakukan perbaikan atau perubahan manakala kebutuhan user sudah tidak relevan dengan sistem kerja perangkat lunak.

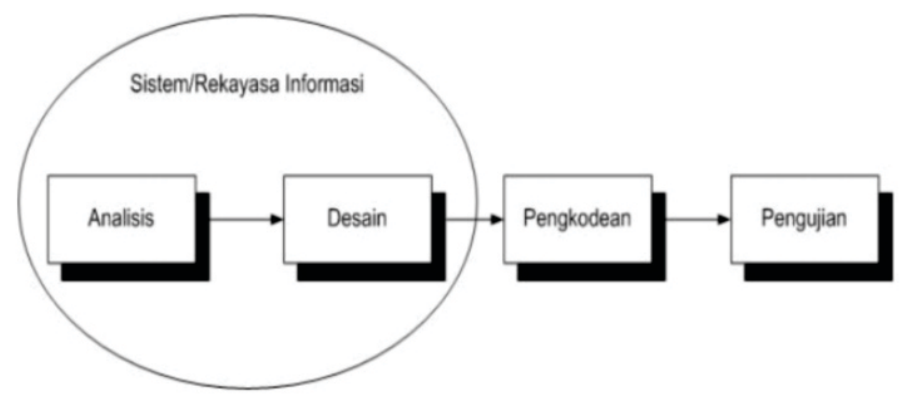

Gambar 2.1 Tahapan Metode Waterfall (Air Terjun) 


\section{PERANCANGAN SISTEM}

a. Use Case Diagram

Use case diagram merupakan pemodelan untuk kelakuan (behavior) sistem informasi yang akan dibuat. Use case diagram mendeskripsikan sebuah interaksi antara satu atau lebih aktor dengan sistem informasi yang akan dibuat. Perancangan use case diagram berdasakan kebutuhan sistem sesuai dengan actor adalah sebagai berikut:

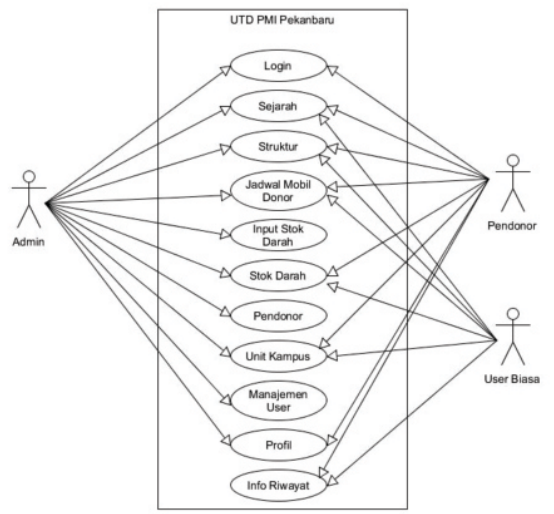

\section{Gambar 4.1 Perancangan Use Case Diagram}

b. Activity Diagram

Activity diagram merupakan gambaran aktivitas yang terjadi dalam sistem yang akan dirancang. Sistem Informasi Donor Darah dimulai dengan pengguna membuka aplikasi dan melihat halaman home dan dihalaman home terdapat beberapa menu, diantaranya untuk membuka halaman info, halaman jadwal, halaman unit, halaman stok darah, halaman profil dan halaman riwayat.

1. Activity Diagram Halaman Utama

Activity Diagram dibawah ini menggambarkan aktivitas pengguna ketika proses melihat halaman utama pada sistem yang ada. Adapun gambar activity diagram halaman utama, sistem dapat dilihat pada gambar 4.2 berikut :

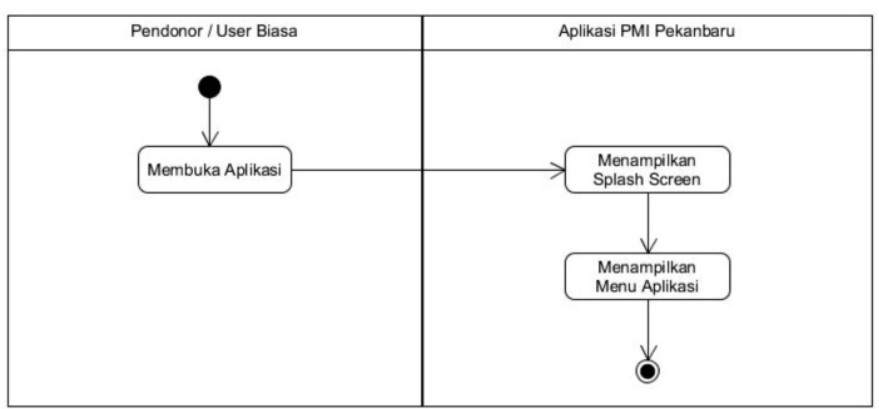

Gambar 4.2 Perancangan Activity Diagram Halaman Utama

\section{Activity Diagram Login}

Activity Diagram dibawah ini menggambarkan aktivitas pendonor ketika proses login pada sistem yang ada. Apabila pendonor ingin menggunakan sistem, harus terlebih dahulu masuk kedalam menu riwayat pendonor dan melakukan login agar bisa masuk kedalam sistem. Adapun gambar activity diagram login pendonor, sistem dapat dilihat pada gambar 4.3 berikut :

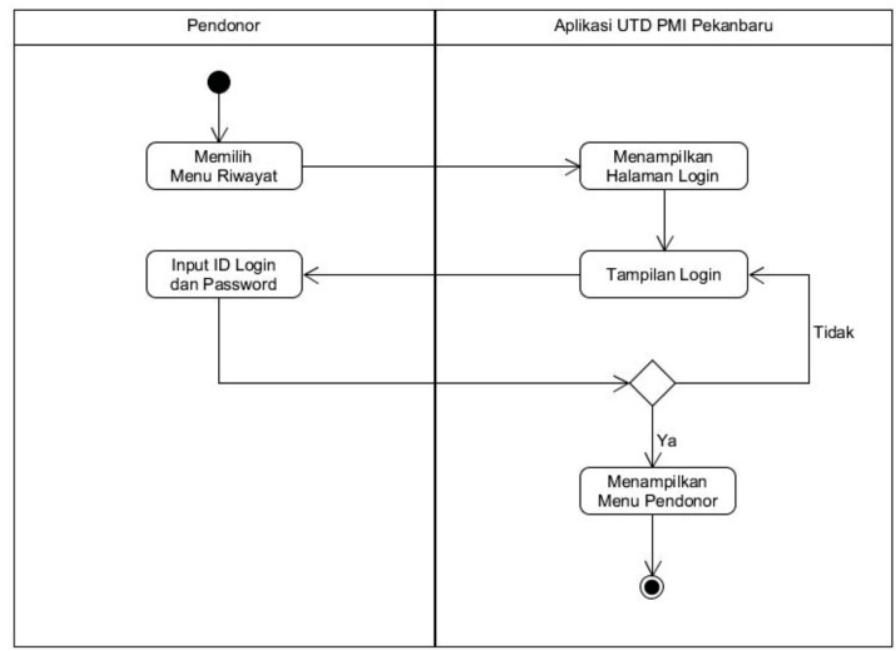

Gambar 4.3 Perancangan Activity Diagram Login

1. Activity Diagram Melihat Profil Pendonor

Activity Diagram dibawah ini menggambarkan aktivitas pendonor ketika proses melihat halaman profil pendonor yang ada di aplikasi donor darah yang sudah ada. Apabila pendonor sudah membuka button profil pendonor, maka akan tampil data pendonor. Adapun gambar activity diagram dapat dilihat pada gambar 4.4 berikut :

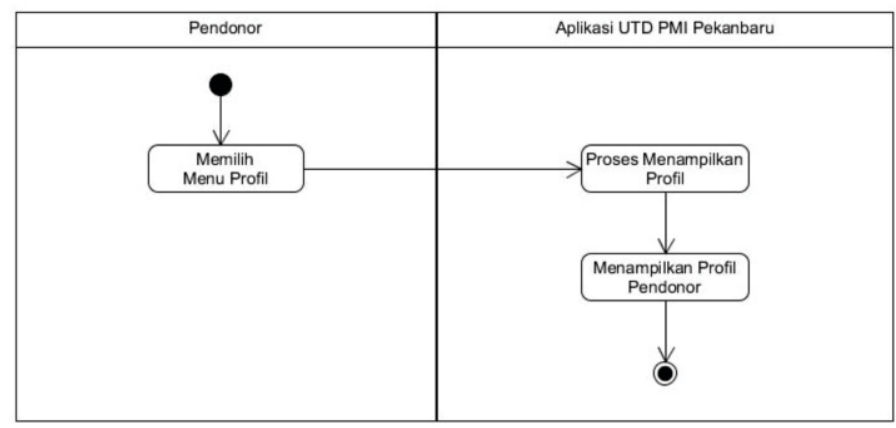

Gambar 4.4 Perancangan Activity Diagram Melihat Profil Pendonor

\section{Activity Diagram Mengupdate Profil Pendonor}

Activity Diagram dibawah ini menggambarkan aktivitas pendonor ketika proses melihat halaman profil pendonor yang ada di aplikasi donor darah yang sudah ada. Apabila pendonor sudah membuka button pendonor, maka akan tampil data pendonor dan mengupdate data pendonor. Adapun gambar activity diagram dapat dilihat pada gambar 4.5 berikut : 


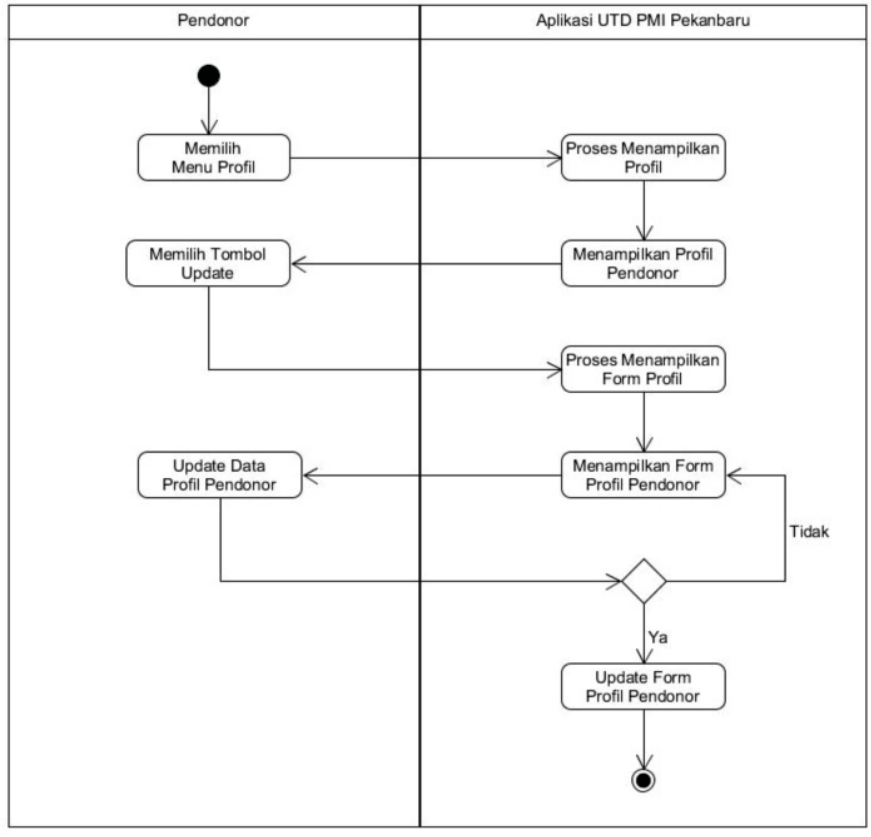

Gambar 4.5 Perancangan Activity Diagram Mengupdate Profil Pendonor

5. Activity Diagram Melihat Riwayat Pendonor

Activity Diagram dibawah ini menggambarkan aktivitas pendonor ketika proses melihat halaman riwayat pendonor yang ada di aplikasi donor darah yang sudah ada. Apabila pendonor sudah membuka button riwayat pendonor, maka akan tampil riwayat pendonor. Adapun gambar activity diagram dapat dilihat pada gambar 4.6 berikut :

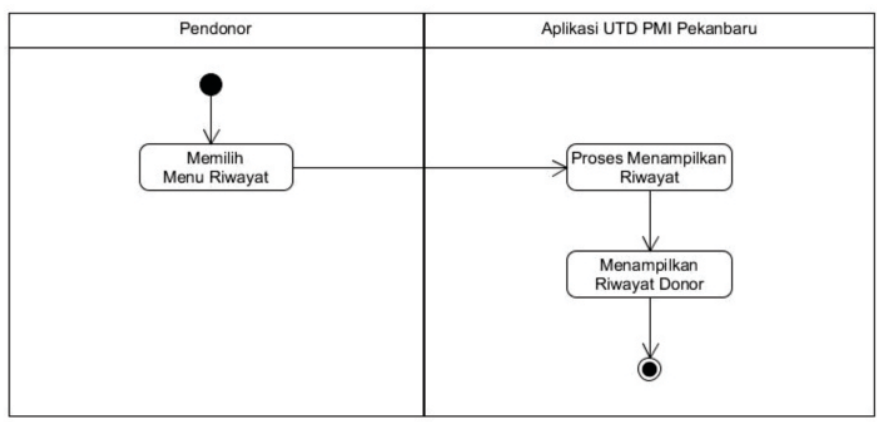

Gambar 4.6 Perancangan Activity Diagram Melihat Riwayat

\section{Pendonor}

6. Activity Diagram Melihat Info

Activity Diagram dibawah ini menggambarkan aktivitas pendonor atau user biasa ketika proses melihat halaman info yang ada di aplikasi donor darah yang sudah ada. Apabila pendonor atau user biasa sudah membuka button info, maka akan tampil syarat dan manfaat pendonor. Adapun gambar activity diagram dapat dilihat pada gambar 4.7 berikut :

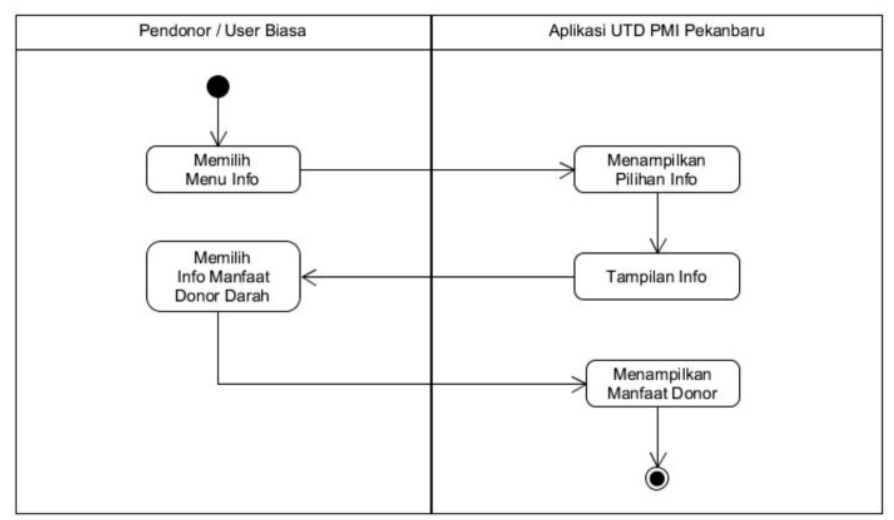

Gambar 4.7 Perancangan Activity Diagram Melihat Info

7. Activity Diagram Melihat Jadwal

Activity Diagram dibawah ini menggambarkan aktivitas pendonor atau user biasa ketika proses melihat halaman jadwal yang ada di aplikasi donor darah yang sudah ada. Apabila pendonor atau user biasa sudah membuka button jadwal, maka akan tampil jadwal pendonor. Adapun gambar activity diagram dapat dilihat pada gambar 4.8 berikut :

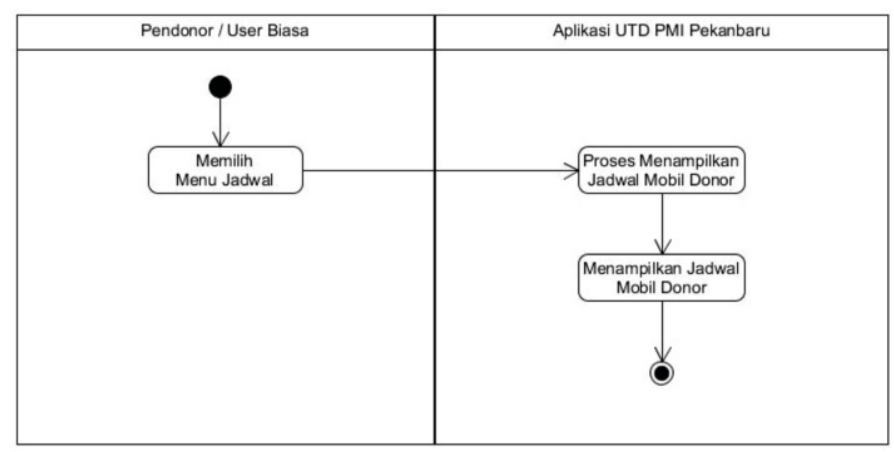

Gambar 4.8 Perancangan Activity Diagram Melihat Jadwal

8. Activity Diagram Melihat Unit

Activity Diagram dibawah ini menggambarkan aktivitas pendonor atau user biasa ketika proses melihat halaman unit yang ada di aplikasi donor darah yang sudah ada. Apabila pendonor atau user biasa sudah membuka button unit, maka akan tampil unit pendonor. Adapun gambar activity diagram dapat dilihat pada gambar 4.9 berikut :

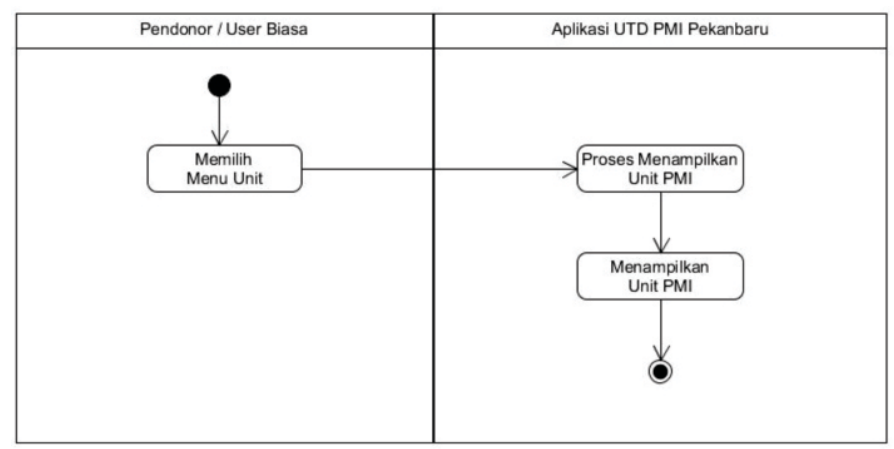

Gambar 4.8 Perancangan Activity Diagram Melihat Jadwal 


\section{Activity Diagram Melihat Stok Darah}

Activity Diagram dibawah ini menggambarkan aktivitas pendonor atau user ketika proses melihat halaman stok darah yang ada di aplikasi donor darah yang sudah ada. Apabila pendonor atau user sudah membuka button stok darah, maka akan tampil stok darah dari pendonor. Adapun gambar activity diagram dapat dilihat pada gambar 4.10 berikut :

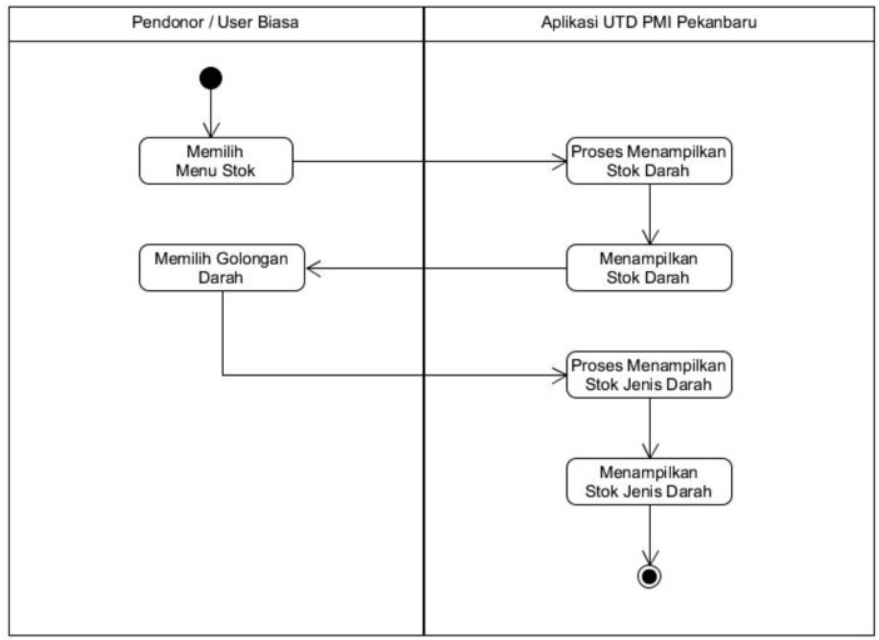

Gambar 4.10 Perancangan Activity Diagram Melihat Stok Darah

10. Activity Diagram Melihat Profil

Activity Diagram dibawah ini menggambarkan aktivitas pendonor atau user biasa ketika proses melihat halaman profil pendonor yang ada di aplikasi donor darah yang sudah ada. Apabila pendonor atau user biasa sudah membuka button profil, maka akan tampil data profil pendonor. Adapun gambar activity diagram dapat dilihat pada gambar 4.11 berikut :

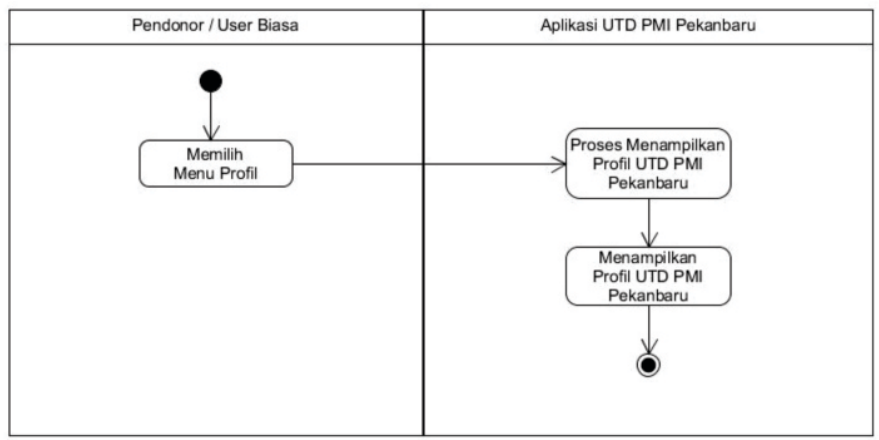

Gambar 4.11 Perancangan Activity Diagram Melihat Profil

c. Class Diagram

Class diagram digunakan untuk menampilkan kelas-kelas dan paket-paket di dalam sistem. Class diagram memberikan gambaran sistem secara statis dan relasi antar class. Berikut adalah gambar dari class diagram dari sistem yang diusulkan.

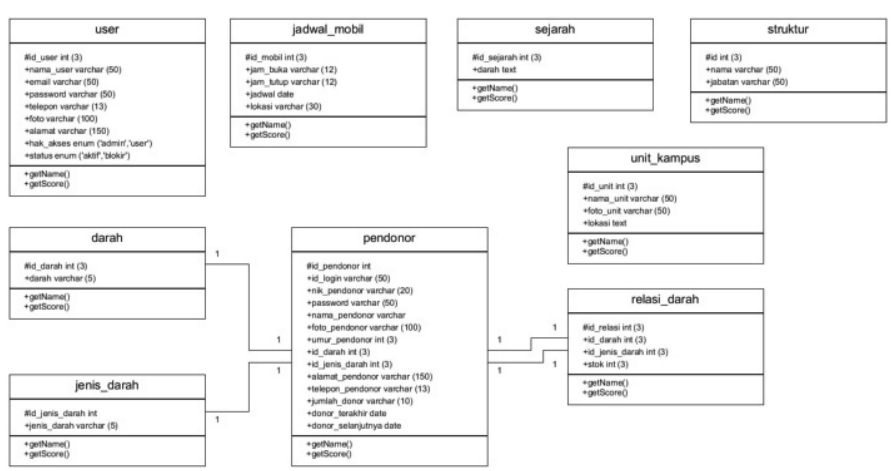

Gambar 4.12 Perancangan Class Diagram

\section{HASIL \& PEMBAHASAN}

\section{Perancangan Antar Muka (Interface)}

a. Perancangan Masukan (Input)

Tampilan input pada sisi admin atau pengguna aplikasi pada android. Tampilan perancangan form untuk sisi admin dirancang menggunakan berbasis mobile agar mudah digunakan kapan saja dan dimana saja.

1. Tampilan Form Input Login Admin

Perancangan tampilan form login merupakan perancangan halaman admin dimana admin harus memasukkan username dan password agar bisa masuk menggunakan sistem. Perancangan tampilan form login admin dapat dilihat pada gambar 4.13

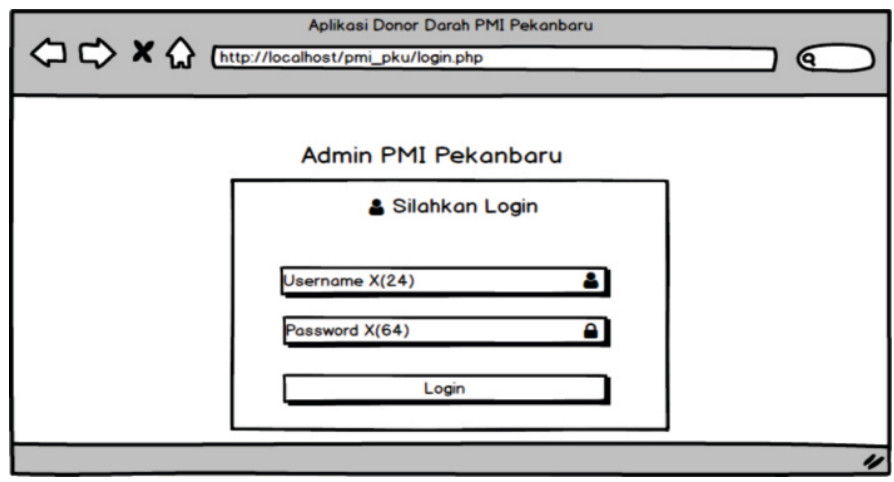

Gambar 4.13 Tampilan Form Login Admin

2. Tampilan Form Input Sejarah

Perancangan tampilan form input sejarah merupakan perancangan halaman dimana admin harus memasukkan data sejarah PMI yang ada. Perancangan tampilan form input sejarah PMI Pekanbaru dapat dilihat pada gambar 4.14.

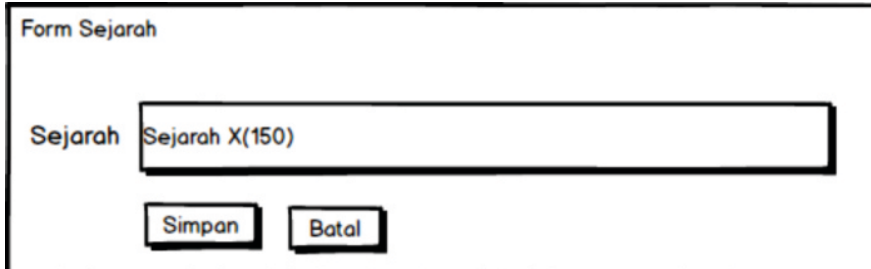

Gambar 4.14 Tampilan Form Input Sejarah 


\section{Tampilan Form Input Struktur}

Perancangan tampilan form input struktur merupakan perancangan halaman dimana admin harus memasukkan data struktur yang ada dengan memasukkan nama struktur dan jabatan. Perancangan tampilan form input struktur PMI Pekanbaru dapat dilihat pada gambar 4.15.

\begin{tabular}{|l|} 
Norm Tambah Struktur \\
Nama Nama X (100) \\
Jabatan Jabatan X (50) \\
\\
\end{tabular}

\section{Gambar 4.15 Tampilan Form Input Struktur}

4. Tampilan Form Input Jadwal Mobil Darah

Perancangan tampilan form input jadwal mobil darah merupakan perancangan halaman dimana admin harus memasukkan data jadwal mobil darah yang ada dengan memasukkan jam buka, tutup, jadwal, dan lokasi yang mendonor. Perancangan tampilan form input jadwal mobil darah PMI Pekanbaru dapat dilihat pada gambar 4.16.

\begin{tabular}{|c|c|}
\hline Form Tambah J & dwal Mobil Donor \\
\hline Jam Buka & Nama X (100) \\
\hline Jam Tutup & Jabatan X (50) \\
\hline Jadwal & Nama $\times(100)$ \\
\hline Lokasi & Jabatan X (50) \\
\hline & Simpan \\
\hline
\end{tabular}

Gambar 4.16 Tampilan Form Input Jadwal Mobil Darah

\section{Tampilan Form Input Stok Darah}

Perancangan tampilan form input stok darah merupakan perancangan halaman dimana admin harus memasukkan data stok darah yang ada dengan memilih golongan darah, jenis darah beserta jumlah yang dimaksud. Perancangan tampilan form input stok darah PMI Pekanbaru dapat dilihat pada gambar 4.17.

\begin{tabular}{|c|c|c|}
\hline \multicolumn{3}{|c|}{ Form Tambah Stok Darah } \\
\hline Golongan Darah & Pilih Golongan Darah X(5) & $\nabla$ \\
\hline Jenis Darah & Pilih Jenis Darah X(9) & $\nabla$ \\
\hline Jumlah & Jumlah X & 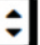 \\
\hline & \begin{tabular}{|l|l|} 
Simpan & Batal \\
\end{tabular} & \\
\hline
\end{tabular}

\section{Gambar 4.17 Tampilan Form Input Stok Darah}

6. Tampilan Form Input Pendonor

Perancangan tampilan form input pendonor merupakan perancangan halaman dimana admin harus memasukkan data pendonor yang ada dengan memasukkan beberapa ketentuan yang ada. Perancangan tampilan form input pendonor PMI Pekanbaru dapat dilihat pada gambar 4.18.

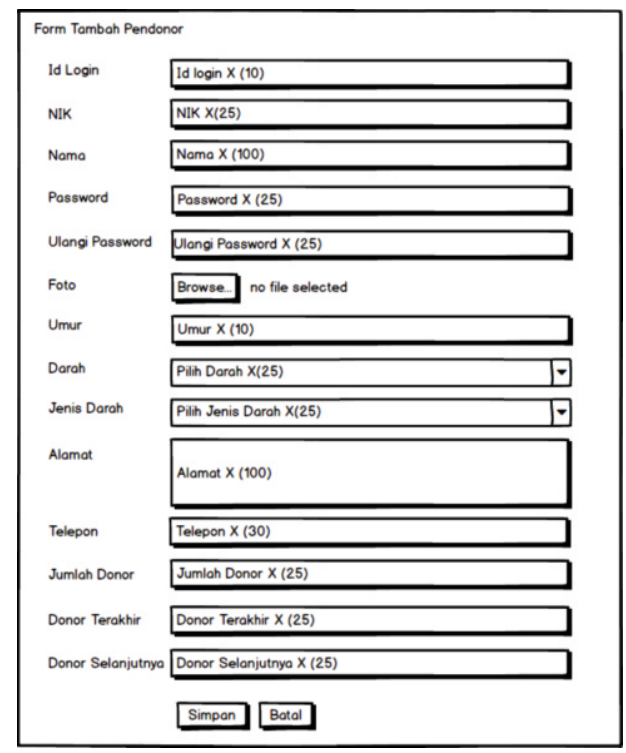

Gambar 4.18 Tampilan Form Input Pendonor

\section{Tampilan Form Input Unit Kampus}

Perancangan tampilan form input unit kampus merupakan perancangan halaman dimana admin harus memasukkan data unit kampus yang ada dengan memasukan nama unit, lokasi beserta memasukkan foto unit yang ada. Perancangan tampilan form input unit kampus PMI Pekanbaru dapat dilihat pada gambar 4.19.

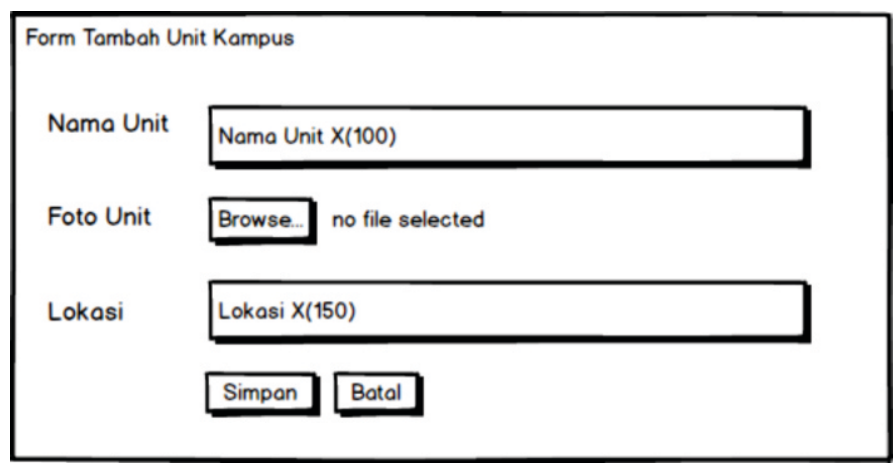

Gambar 4.19 Tampilan Form Input Unit Kampus

b. Perancangan Output

Perancangan output adalah keluaran dari sistem atau dapat juga disebut sebagai laporan. Berikut ini adalah perancangan output pada aplikasi.

\section{Tampilan Splash Screen}

Perancangan tampilan splash screen aplikasi merupakan tampilan splash screen yang akan dilihat oleh pengguna saat pertama kali menggunakan aplikasi. masuk kedalam aplikasi. 
Tampilan splash screen aplikasi android dapat dilihat pada gambar 4.20 berikut :

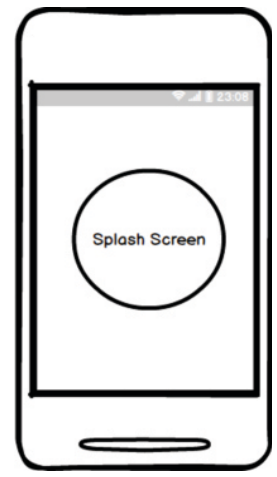

Gambar 4.20 Tampilan Splash Screen

2. Tampilan Output Halaman Utama Aplikasi

Perancangan tampilan halaman utama aplikasi merupakan tampilan halaman yang akan dilihat oleh pengguna saat pertama kali masuk kedalam aplikasi. Tampilan Output halaman utama aplikasi android dapat dilihat pada gambar 4.21 berikut:

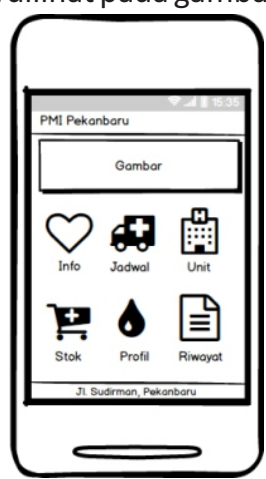

Gambar 4.21 Tampilan Output Halaman Utama Aplikasi

3. Tampilan Output Halaman Info Donor Darah

Perancangan aplikasi tampilan halaman info donor darah merupakan tampilan halaman yang akan dilihat oleh pengguna saat menekan button Info. Pada halaman Info Donor Darah pengguna dapat melihat 2 kategori yang memberikan informasi tentang syarat donor darah dan manfaat donor darah. Tampilan Output halaman info donor darah di aplikasi android dapat dilihat pada gambar 4.22 berikut :

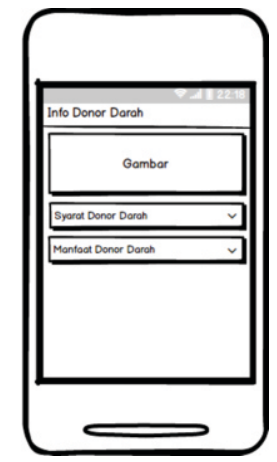

Gambar 4.22 Tampilan Output Halaman Info Donor Darah 4. Tampilan Output Halaman Jadwal Mobil Donor Perancangan aplikasi tampilan halaman dari kategori jadwal mobil donor merupakan tampilan halaman yang akan dilihat oleh pengguna saat menekan salah satu button kategori di jadwal mobil donor. Pada halaman isi dari kategori jadwal mobil donor pengguna dapat melihat beberapa sub menu yang memberikan informasi tentang jadwal mobil donor berbentuk jadwal, jam buka, jam tutup, dan lokasi. Tampilan Output halaman isi dari kategori jadwal mobil donor di aplikasi android dapat dilihat pada gambar 4.23 berikut :

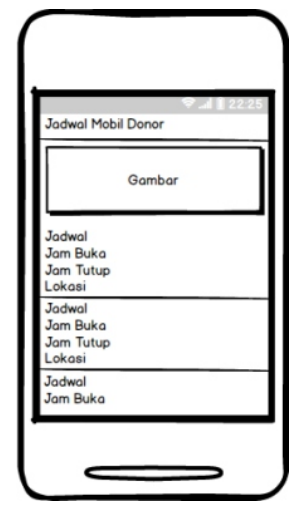

Gambar 4.23 Tampilan Output Halaman Jadwal Mobil Donor

5. Tampilan Output Halaman Unit PMI

Perancangan aplikasi tampilan halaman unit PMI merupakan tampilan halaman yang akan dilihat oleh pengguna saat memillih unit PMI. Pada halaman unit PMI pengguna dapat melihat informasi tentang unit PMI. Tampilan Output halaman unit PMI di aplikasi android dapat dilihat pada gambar 4.24 berikut :

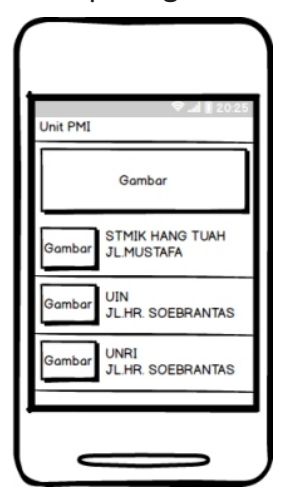

\section{Gambar 4.24 Tampilan Output Halaman Unit PMI}

6. Tampilan Output Halaman Stok Darah

Perancangan aplikasi tampilan halaman stok darah merupakan tampilan halaman yang akan dilihat oleh pengguna saat menekan button stok darah. Pada halaman stok darah pengguna dapat melihat informasi tentang stok disetiap golongan darah. Tampilan Output halaman isi dari kategori stok darah di aplikasi android dapat dilihat pada gambar 4.25 berikut : 


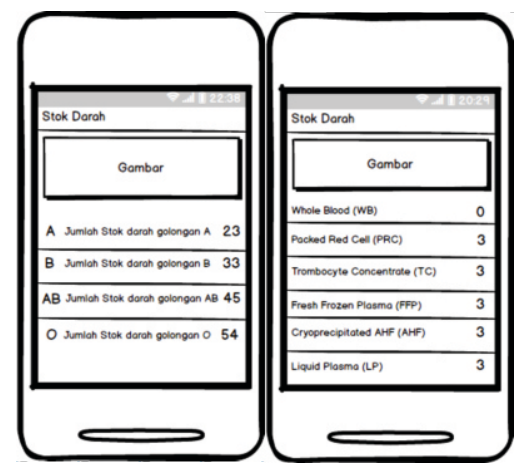

Gambar 4.25 Tampilan Output Halaman Stok Darah

7. Tampilan Output Halaman Profil

Perancangan aplikasi tampilan halaman profil merupakan tampilan halaman yang akan dilihat oleh pengguna saat memillih profil. Pada halaman profil pengguna dapat melihat informasi sejarah dan struktur dari UTD PMI Pekanbaru. Tampilan Output halaman profil di aplikasi android dapat dilihat pada gambar 4.26 berikut :

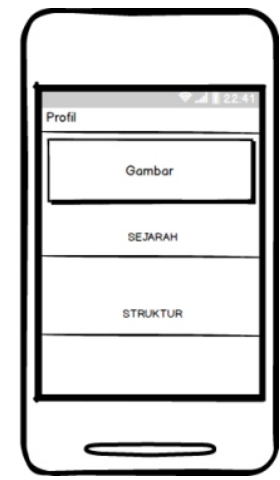

Gambar 4.26 Tampilan Output Halaman Profil

8. Tampilan Output Halaman Login Pendonor

Perancangan tampilan Output login pendonor merupakan perancangan halaman pendonor dimana pendonor harus memasukkan username dan password agar bisa masuk menggunakan sistem. Tampilan Output halaman Login Pendonor di aplikasi android dapat dilihat pada gambar 4.27 berikut :

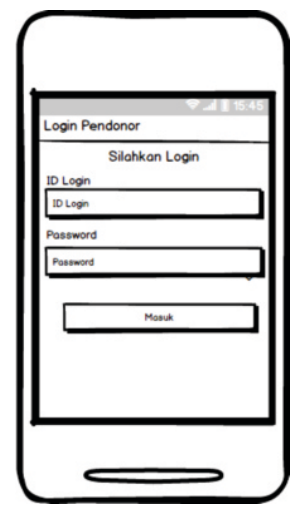

Gambar 4.27 Tampilan Output Halaman Login Pendonor

9. Tampilan Output Halaman Pendonor PMI Pekanbaru Perancangan tampilan Output pendonor PMI Pekanbaru merupakan perancangan halaman pendonor dimana pendonor berisi profil dan riwayat pendonor. Tampilan Output halaman Pendonor PMI Pekanbaru di aplikasi android dapat dilihat pada gambar 4.28 berikut :

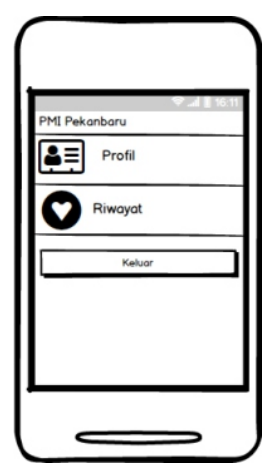

Gambar 4.28 Tampilan Output Halaman Pendonor PMI Pekanbaru

10. Tampilan Output Halaman Utama Sistem

Perancangan tampilan halaman utama sistem merupakan perancangan halaman yang tampil saat user dengan hak akses admin pertama kali masuk kedalam sistem. Tampilan Output halaman utama sistem dapat dilihat pada gambar 4.29 berikut :

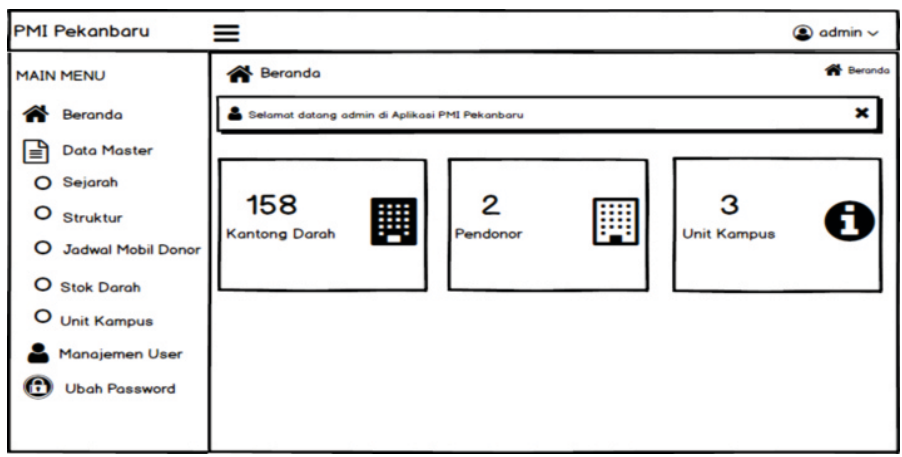

Gambar 4.29 Tampilan Output Halaman Utama Sistem

\section{KESIMPULAN DAN SARAN}

1. Kesimpulan

Dari hasil penelitian pembuatan sistem informasi donor darah berbasis android ini dapat diambil beberapa kesimpulan sebagai berikut:

1.Sistem informasi donor darah berbasis android pada UTD PMI Kota Pekanbaru ini sudah berbentuk aplikasi android yang dapat diakses tanpa browser atau secara mobile. Aplikasi ini dibangun berdasarkan tahapan-tahapan dari metode pengembangan waterfall.

2.Berdasarkan pengujian, sistem informasi donor darah berbasis android ini sudah memenuhi tujuan dari rumusan masalah yang ingin dicapai oleh penulis.

3.Sistem informasi donor darah berbasis android ini dapat berjalan atau berfungsi dengan baik, termasuk seluruh fiturfitur yang melekat pada sistem informasi donor darah berbasis android ini.

2.Saran

1.Sistem informasi donor darah berbasis android ini 
disarankan untuk menggunakan data yang lebih lengkap sehingga informasi yang disajikan menjadi lebih baik dan lebih maksimal.

2.Pengembangan sistem informasi donor darah berbasis android ini disarankan agar dapat melakukan proses pelayanan permintaan darah yang diajukan oleh Rumah Sakit.

\section{DAFTAR PUSTAKA}

Ermatita. 2016. Analisis Dan Perancangan Sistem Informasi $\begin{array}{llllllllllllllll}P & e & r & p & u & s & t & a & k & a & a & n\end{array}$. http://download.portalgaruda.org/article.php?arti cle $=472252 \&$ val $=5840 \&$ title=ANALISIS\%20DAN\%20 PERANCANGAN\%20\%20SISTEM\%2OINFORMASI\%2 OPERPUSTAKAAN diakses pada [Senin, 25 September 2017. Jam 04:17 Wib].

Fuadda, Rahmatul., dkk. 2016. Perbedaan Reaksi Pemberian Transfusi Darah Whoole Blood (Wb) Dan Packed Red Cell (Prc) Pada Pasien Sectio Caesare.

https://www.google.co.id/url?sa=t\&rct=j\&q=\&esrc=s\&so urce=web\&cd=1\&cad=rja\&uact=8\&ved=0ahUKEwi $\mathrm{P} 2 \mathrm{~d}$ 6vNXWAhUGJ5QKHZ81Am4QFggoMAA\&url=https \%3A\%2F\%2Fojs.fdk.ac.id\%2Findex.php\%2Fhumanc are\%2Farticle\%2Fdownload\%2F29\%2Fpdf\&usg=AO vVaw2fx5MSsjbImUOk9neVxZV0diakses pada [Selasa, 26September 2017. Jam 05:15 Wib].

Hapsari, Nur Yuli Dwi., Herdiana, Ike. 2012. Hubungan Antara Self-Esteem Dengan Intensi Perilaku Prososial Donor Darah pada Donor Di Unit Donor Darah PMI $\begin{array}{llllllll}S & u & r & a & b & a & y & a\end{array}$. http://www.journal.unair.ac.id/downloadfullpapers-jpksde3108ea962full.pdf diakses pada [Senin, 30 September 2019. Jam 12.08 Wib].

Hendini, A. (2016). Pemodelan UML Sistem Informasi Monitoring Penjualan dan Stok Barang (Studi Kasus: Distri Zhezha Pontianak). Jurnal Khatulistiwa Informatika, IV(2).

Hermawan S., Stephanus. 2011. Mudah Membuat Aplikasi Android. Andi. Yogyakarta.

Mario Fernando. 2013. Membuat Aplikasi Android Augmented Reality Menggunakan Vuforia SDK dan Unity.

Suherman, Yanni. 2017. Sistem Aplikasi Bank Darah Pada Palang Merah Indonesia Payakumbuh.

http://ejournal.kopertis10.or.id/index.php/sains/article/d ownload/2329/80 diakses tanggal [Minggu, 29-092019, Pukul 7.39 Wib].
Sugiatno, Castaka Agus. 2017. Rancang Bangun Aplikasi Donor Darah Berbasis Mobile di PMI Kab Bandung. https://media.neliti.com/media/publications/2270 24-rancang-bangun-aplikasi-donor-darah-berb942afb1f.pdf diakses tanggal [Minggu, 29-09-2019, Pukul 7.30 Wib].

Sukamto, Rosa Ariani dan Shalahuddin, M. 2016. Rekayasa Perangkat Lunak. Informasi Bandung. Bandung.

Polinema, J. I. (2018). Penerapan Web Service Dan Firebase Notification. Jurnal Informatika Polinema, 4(2), 161-167.

Warman, Indra., Saputra, Keni Novandri. 2012. Sistem Informasi Alumni ITP Menggunakan PHP Dan MySQL.

https://ejournal.itp.ac.id/index.php/momentum/article/v iewFile/87/84 diakses pada [Selasa, 26 September 2017. Jam 12.02 Wib].

Yakub. 2012. Pengantar Sistem Informasi. Graha IImu. Yogyakarta.v 